\title{
Community Empowerment and Social Media Models as Marketing Communication Innovations for Local Culinary Products in Serang, Indonesia
}

\author{
Nurprapti Wahyu Widyastuti $1^{*}$ Abdelrahman Ali ${ }^{2}$ Rahmi Winangsih ${ }^{1}$ Hidayatullah Haila ${ }^{3}$ \\ ${ }^{I}$ Social and Political Science, Sultan Ageng Tirtayasa University Jl. Raya Jakarta Km 4 Serang - Banten, Indonesia \\ ${ }^{2}$ LSPR Communication and Business Institute, Campus C, Sudirman Park Campus - Jl. K.H Mas Mansyur, Kav. 35, Jakarta \\ ${ }^{3}$ Deparment of Education Science Sultan Ageng Tirtayasa University Jl. Raya Jakarta Km 4 Serang - Banten, Indonesia
}

${ }^{*}$ Corresponding author. Email: nurprapti.wahyu@untirta.ac.id

\begin{abstract}
Indonesia is predicted to experience demographic bonuses during the period 2025-2030. Consequently, the Indonesian government is required to provide employment opportunities, food sufficiency, and other basic needs. At the same time, Indonesia has been facing the challenges and problems resulted from the implementation of ASEAN Economic Community (AEC). Food security is a strategic issue because it is closely related to social, economic, and political stability. Food security is realized through increasing domestic production capabilities and improving the management of food reserves and distribution. The fundamental relevant question is how to build community empowerment model through community learning marketing communication groups to market local culinary products in Serang, Banten Province, Indonesia.

Food security is not only limited to local food production but also covers sustainability. In line with the development of information technology, local food production can be marketed with a wider reach and cross territorial boundaries through online marketing communication media. In order to achieve these ideal goals, local communities need to be empowered through the creation of learning groups to execute some empowerment activities.

This article reports the findings of research which reveal

(1) learning model for local culinary marketing communication. and (2) Online consumer behaviour of social media innovation as tools of marketing communication.
\end{abstract}

Keywords: Community Empowerment Model, Marketing Communication innovation, Learning Group, Food Security, Local Culinary

\section{INTRODUCTION}

Policies related to food security actually have been adopted by the government of Indonesia since 1970. The government's attention to food security is getting higher and more serious. Food security can be explored through four aspects, namely national food policy, rice self-sufficiency, dependence on imported food, and empowerment of farmers (Suryana 2008). To meet domestic food needs, it is necessary to optimize the performance of the food economic system, which includes the production, distribution and consumption subsystems.

These three subsystems are integrated, unified, and interact with each other, and continuously supported by natural resources, institutional, cultural and technological inputs. This process will run efficiently if it is supported by community participation and an effective communication and information system. For a long time, it has been recognized that food is not only act as an economic commodity but also becomes a social and even political commodity.

Shortages in food and nutrition can lead to critical situations that would threaten national stability and undermine the ruling government. Constitutionally, food is defined as fundamental issue as stated in article 27 of the Indonesian Constitution and Law No.7 of the year 1996 concerning food (Parlaungan Adil Rangkuti, 2009; 28). To create food security, aspects of food safety, quality, and diversity are conditions that must be met in order to fulfil food needs sufficiently, evenly and affordably. The government's commitment to realize food self-sufficiency is mandated by Indonesia`s LongTerm National Development Plan (RPJPN) 2005-2025.

Food security can be interpreted as the ability to guarantee that all residents could obtain sufficient food with a decent and safe quality. To make it happen, it needs the support of various elements, including the government, higher education and/or research institutions, the business community, and nongovernmental organizations.

Each region or local community has its own characteristics and unique local wisdom that distinguish and differentiate the perspective region or community. Culinary is one of the local wisdom that can be used as economic potential, especially if commodification is carried out. Commodification is closely 
related to the creative world. For this reason, efforts need to be made to encourage this industry to be more creative, especially in terms of food diversity, packaging, distribution and use of marketing communication media.

The current problem faced by producers and local culinary entrepreneurs is the limited market reach due to lack of ability to market local culinary products. This problem is actually a classic problem experienced by small enterprises in general. Previous studies conducted by the author indicate a positive trend that can be developed as a potential movement for the success of the food security program and community selfreliance.

One of these positive movement is the emergence of collective awareness on local entrepreneurs related to the use of social media as a medium of marketing communication. This movement is initially emerged due to lack of preparedness to face the free trade in South East Asia after the implementation of ASEAN Asian Economic Community in 2015. On the other hand, business actors also realize that rapid technological changes also affect market behaviour, consumer behaviour, and marketing communication media. However, this movement is sporadic, unplanned, and is not managed optimally. This article explores how the local community in Serang, Indonesia would perform self-management to develop learning group model in accordance with community empowerment standards.

\section{LITERATURE REVIEW}

Several previous studies highlight the need for human resources that are adaptive to changes. Community empowerment begins with the formation of independent learning groups within and among small enterprises. This section presents literature review related to research concepts and topics. Community empowerment is an effort to provide empowerment or strengthening to the community. Community empowerment is also defined as the ability of individual member in a community to develop empowerment of the concerned community so as to find new alternatives in community development. Community empowerment is interpreted as both process and purpose. As a process, empowerment is a series of activities to strengthen weak groups in society, including individuals who experience poverty problems. Meanwhile, empowerment as a goal refers to the desired results to be achieved by social change, such as the creation of empowered society that has the power, knowledge, and ability to fulfil their physical, economic and social needs. These social needs are such as self-confidence, convey aspirations, have a livelihood, participate in social activities, and be independent in carrying out the daily life activities.

Community empowerment is an effort to enable community self-reliance to carry out by the following efforts:

1. Enabling: refers to creating an atmosphere or climate that allows and assists in developing the community`s potential
2. Empowering, capacity building by strengthening the potentials and abilities of the community.

3. Protecting, protecting interests by developing a protection system for the subject of development.

In general, the goal of community empowerment is to (1) Better Institutions: institutional improvements is expected to be achieved as a result of business activities and practices, including the development of business partnership networks. (2) Better Business, improving education (enthusiasm for learning), improving access to business, and institutional improvements, are expected to improve the business. (3) Better Income, with the business improvement being carried out, it is expected that it will lead to income increase, including the income of the family and the community. (4) Better Environment, improved income is expected to improve the environment (physical and social) because environmental damage is often caused by poverty or limited income. (5) Better Living, income increase and improved environmental conditions are expected to improve the living conditions of every family and community. (6) Better Community: a better life, which is supported by a better environment (physical and social), is expected to manifest a better community life. Based on these points, community empowerment becomes urgent to accelerate efforts to achieve food security.

Marketing strategy is a set of objectives, policies, and rules that underline the direction of the company's marketing efforts. The marketing strategy is made primarily as the company's response to the ever-changing competitive environment. Therefore, determining the marketing strategy must be based on both internal external analysis the company's strengths and weaknesses, as well as an analysis of the opportunities and threats faced by the company from its environment.

Environmental factors that analysed in the preparation of marketing strategies, are market conditions or competition, technological developments, economic conditions, government regulations and policies, socio-cultural conditions, and political conditions. Each of these factors can create opportunities or obstacles to market the company's products. Basically, marketing activities are communication activities. This is due to the process of communicating product characteristics, including communicating the product value and its benefits. The purpose of the marketing communication will be very different in the strategy or the tactics carried out by the manufacturer/marketer to win the competition.

The increase of internet users every day is not just ignored by business people. Today many business people deliberately make websites, blogs, or create accounts on Facebook and Twitter for Company promotion or marketing their products. This progress is considered very useful to be used as one of the business marketing strategies. Business promotion via the internet is one way to expand market reach as well as corporate promotions. Through internet marketing, product information can reach consumers in regions without having to go directly to the area to promote products. 


\section{METHODOLOGY}

The research depended on qualitative research to explore in-depth information on various aspects related to community empowerment, study groups and marketing strategies for creative industry products for the people of Serang region. The research is descriptive qualitative research with a case study approach. Data was collected from various sources from industry, fisheries, and maritime departments, business actors and the culinary business community in Serang, Banten province. The following table shows key informants who provide data and information about the culinary business, business community, and government.

TABLE 1: THE PROFILE OF PARTICIPANTS

\begin{tabular}{|l|l|l|l|}
\hline No. & Name & Description & $\begin{array}{l}\text { Date of } \\
\text { Interview }\end{array}$ \\
\hline 1 & Corry & $\begin{array}{l}\text { Department of Industry and } \\
\text { Commerce }\end{array}$ & $\begin{array}{l}\text { 04 September } \\
2018\end{array}$ \\
\hline 2 & Ebi & $\begin{array}{l}\text { Department of Industry and } \\
\text { Commerce }\end{array}$ & $\begin{array}{l}04 \text { September } \\
2018\end{array}$ \\
\hline 3 & Ekawati & $\begin{array}{l}\text { Department of Fisheries and } \\
\text { Marine }\end{array}$ & $\begin{array}{l}\text { 09 August } \\
2018\end{array}$ \\
\hline 4 & Sukarno & $\begin{array}{l}\text { Chairman of the POKLAHSAR } \\
\text { Jaya Cooperative in Serang }\end{array}$ & $\begin{array}{l}\text { 09 August } \\
2018\end{array}$ \\
\hline 5 & Ceppy & $\begin{array}{l}\text { Culinary Entrepreneur } \\
\text { Community }\end{array}$ & 26 July 2018 \\
\hline 6 & Asyrof & TDA Business Community & 31 July 2018 \\
\hline 7 & $\begin{array}{l}\text { Agus } \\
\text { Mulyanto }\end{array}$ & Local Culinary Entrepreneur & $\begin{array}{l}16 \text { August } \\
2018\end{array}$ \\
\hline 8 & Ratu Toety & Local Culinary Entrepreneur & $\begin{array}{l}21 \text { August } \\
2018\end{array}$ \\
\hline 9 & Mulyati & Local Culinary Entrepreneur & $\begin{array}{l}26 \text { September } \\
2018\end{array}$ \\
\hline
\end{tabular}

Data collection is done by interview, observation and Focus group discussion. Data Validity Technique is carried out by triangulating resource persons, techniques and time.

\section{RESULT}

\section{A. Community Empowerment Model Towards Food Security}

Community empowerment towards food security is an ongoing process and requires synergy between subsystems. Each subsystem has a role that matches its capacity. In the context of this research, community empowerment is carried out by the industry and trade offices, and the fisheries and maritime service as a representation of the local government. The central role of government institutions is to create a conducive climate to develop the local community potential and to protect the community interests by developing a protection system for the people who are the subject of protecting. On the other hand, the basic role of universities/research institutions and non-governmental organizations is developing and building capacity by strengthening the potential and strength of the community. Synergy between these subsystems can be seen in Figure 1 below:

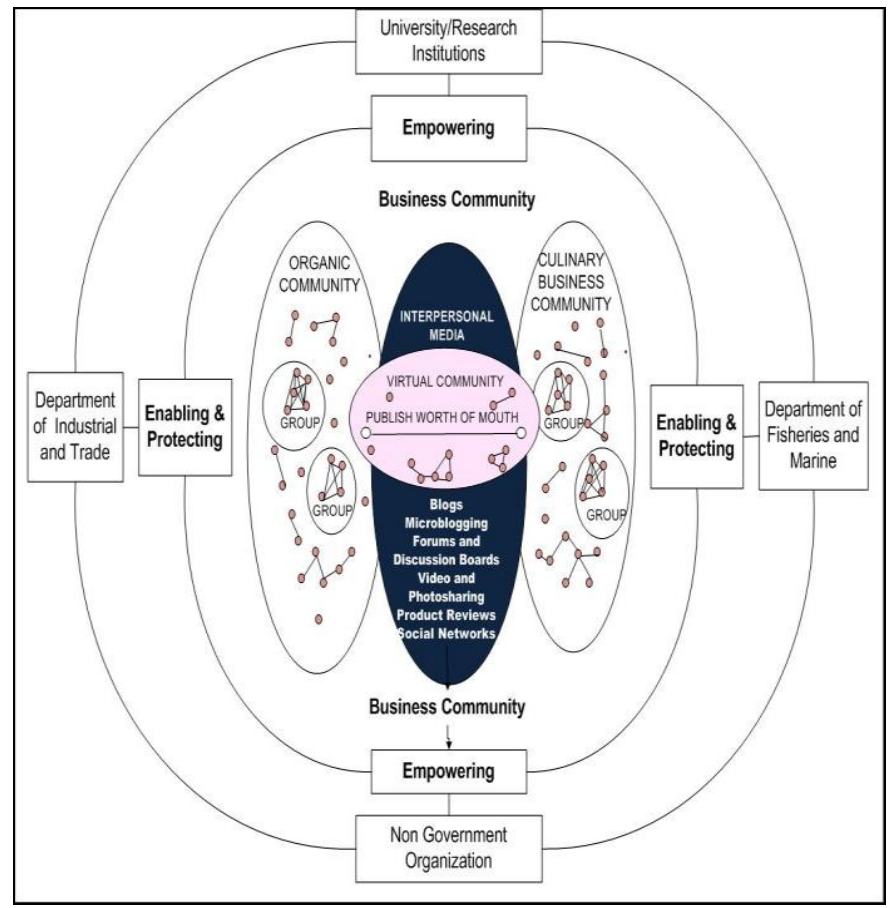

Figure 1: Community Empowerment Model Towards Food Security

It is well documented that global competition is the direct impact of communication and information technology on small businesses. It is interesting to find out that mastery of technology is the main obstacle. Their lack of understanding of the use of hardware and software as well as marketing communication systems encourages them to form communities. This community eventually became the agent of change.

The most prominent agent of change is an entrepreneur community called Komunitas Tangan Di Atas (TDA). This non-profit organization is purely a social organization and has branches in major cities throughout Indonesia. The current management of TDA includes the central TDA and regional TDA. The TDA administrators are well aware that the spearhead of the Indonesian economy is in the SME scale business. Therefore, TDA's vision is to form tough and successful entrepreneurs who have a positive contribution to civilization. To face the demographic bonus, one of their missions is to develop entrepreneurial spirit and form 10,000 formidable and successful billionaire entrepreneurs until 2018. This is an accurate strategy to face the ASEAN Economic Community and the demographic bonus of 2020-2030.

Members of the TDA community hold regular meetings, seminars, workshops, and mentoring. The aim of these activities is "learning together". This concept is similar to the concept of "foster father" or "foster brother", where established entrepreneurs foster and guide smaller entrepreneurs or newcomers ("newbies"). In the context of a culinary business, the learning communication marketing community, in addition to being guided by the TDA 
community, they also form cooperatives such as the POKLAHSAR Jaya cooperative in Serang City. POKLAHSAR refers to processing and marketing groups. At first, this Cooperative started as a gathering of producers of "Sate Bandeng" which is a popular sate made of deboned milkfish. Their activities focus on milkfish processing and marketing activities. However, along with its development, this cooperative focuses more on holding regular meetings and discussions to discuss topics related to business development and marketing communication, including marketing using the internet.

The above figure shows that individual dependence on smartphones is becoming very high. The figure shows the anatomy of the community where individuals can join groups, connected in cyberspace networks. The existence of social media makes it easier to get information, communication, and coordination. Resources are abundant and very easy to get. Communication channels become interpersonal and can be published with social media. This means that interpersonal chats can be published in the presence of social media. This is known as "word of mouth. One consequence of word of mouth is that every individual social media user can be a message creator and at the same time as a message distributor. Individuals can easily create blogs, microblogging, forums and discussion boards, photo sharing, product reviews, and social networks.

The ease of communication and information distribution is now being addressed as an opportunity for entrepreneurs. At the very least, with the presence of social media can decrease the costs of marketing and promotional communications. It is known that small enterprises do not have a big promotional budget. They rely on word of mouth marketing and exhibitions held by the government. This reasoning makes them joyfully gather and group together to make the community learn marketing through social media. Currently, they use Facebook, Twitter, WhatsApp, and Instagram to promote their culinary products.

The social system in Serang, Banten province is a system that is open to change. During this time in history, it was recorded that the people of Banten, especially in the four major cities, were known as cosmopolitan communities. The Community is diverse society of various ethnicities and they coexist harmoniously. This diversity makes them live complementary. The phenomenon that stands out in togetherness is when the community is confronted with the enactment of the ASEAN Economic Community (AEC) Zone. The SME entrepreneurs studied together in various internet marketing discussions and trainings organized by communities, industry and trade services, fisheries and marine services and non-governmental organizations. This leads to sharing business experience, sharing business strategies, and networking. This phenomenon is what researchers describe as the most important part that strengthens SME managers in facing free competition in the global era. The openness of this social system is of course related to the prevailing social norms of the people of Banten province.

\section{B. Consumer Investment and Online Consumer Behaviour of Social Media Innovation as A Medium of Marketing Communication}

In the era of new media where people already have a high dependence on the virtual world community using application users and the number of visitors who are expected to continue to increase. The more followers / and / friends, the more profitable they will be for their SME managers who are connected is a potential market that has been segmented and has the same interest. This is a very valuable capital, like a hunt that has entered the trap. What the SME managers need is to use them for the purpose of marketing their products.

The adoption of new media innovations in business was initially started by large multi-national companies, followed by professional workers in the national oil companies and workers in departments with a high level of education. The next Adopter is the SME's business managers and the last is the household consumers and individual purchases. These are the final adopters. However, these late adopters are important for the development of the business sector today. The late adopter have encouraged entrepreneurs to invest in improving and even changing infrastructure on a large scale.

History shows that in the mid-1990s European countries, America, Canada and several countries in Asia have gone through an important part of the era of computer technology, internet, and telecommunications. During that period there were significant breakthroughs in the use of PCs, digital and mobile phones, electronic mail, and the internet, for the consumption of household networks. At present, the internet has even become part of being integrated with communities in developing countries. This shows that the process of diffusion of new media innovations is going well. Environmental demands have forced the final adopting countries to continue to adapt to technological advances.

There are three characteristics that are interrelated in relation to the adoption of new media at the level of household and individual consumption. First is the view of the supply of design, products, and marketing from new media. It is important to realize that in the future, lifestyle, comfort and benefits and communication capacity will change dramatically. Dependence on cyber media will become stronger. Therefore, the market and economic trade will gradually shift from offline to online even though each other does not mutually kill each other. Both will support each other. The rapid development of information technology will change the current business and professional models. In the future, there will be business and professional models that have not been defined yet. As an example of a business model with online media based such as gojek and business derivatives, online shop, marketplace (bukalapak, matahari mall, etc.) in 5-10 years this business model has not been defined. Second, technology both hardware and software will always be developed to facilitate 
the use of applications for improving life quality. In this context, the diffusion and adoption of innovation will always be done to reduce international gaps and improvements in the global era. Third, technology both hardware and software will affect individual social life. Many individual and social relationships are based on relationships formed through social media networks. New rules of the game are needed to accommodate any changes that will occur.

It is very important to remember, that the diffusion process occurs in a social system. There are four factors that influence the innovation-decision process. The four factors are 1) social structure, 2) system of social norms, 3) opinion leaders, 4) reform agents. Social systems are a set of interconnected units that are incorporated in a joint problemsolving effort to achieve a goal. This diffusion process in relation to the social system in Banten province is influenced by social structure, social norms, and the role of leaders and agents of change, types of innovation decisions and consequences of innovation.

Norm is a pattern of behaviour that can be accepted by all members of the social system that serves as a guide or standard for all members. This norm system is closely related to the degree of compatibility with the value or trust of the community in a social system. So, the degree of incompatibility of an innovation with the beliefs or values adopted by individuals (a group of people) in a social system influences the acceptance of these innovations (Shimp, 2003; 279).

Based on the above description and the researchers' observations, the existence of social media has a high degree of conformity with the current conditions. Social media can help SME managers in communicating their products by using it as a marketing communication medium. What's interesting about this research is the active role of opinion leaders in the process of adopting social media as a marketing communication medium for this SME product.

Opinion leaders are influential people, namely certain people who are able to influence the attitude of others informally in a social system. This influential person can be a supporter of innovation or being an opponent of innovation adoption. In reality, the process of adopting social media in Banten province also involves leader opinion.

They act as models in which their behaviour is followed by their followers. These opinion leaders are senior SMEs who have established business networks. They are not always the ones who control social media as a medium of marketing communication, but their attitude supports the adoption of innovation. They are the ones who are used as references in each community discussion. They also facilitate junior SMEs to study business and online marketing communications. So, it is clear here that opinion leaders play a role in the innovationdecision process. In addition to the existence of opinion leaders, in the process of adopting social media, there is also an agent of change.
Agent of change is a part of a social system that influences its social system. They are people who can influence the attitude of others to accept an innovation. But change agent has official or formal capacity, and he gets the assignment from his client to influence people in his social system (Singhal, et. all, 2006; 35). Agent of change or reforming agent as called in Indonesian language, is usually a professional person who has received certain education or training to be able to influence his social system. In this study, the initiator of change is not from the government. Innovation initiatives to answer global market changes are actually from the business community namely Komunitas Tangan Di Atas (TDA). Long before the government -through the industry, trade services, and fisheries maritime services- intervened to help SME managers who act as reform agents representing the entrepreneur community. These managers have become more united and working hand in hand to progress and develop together to face the global market competition that resulted from the implementation of ASEAN Economic Community.

\section{CONCLUSION}

The demand to survive and exist in the ASEAN region free trade situation must be addressed positively and optimistically. Advances in technology and the internet make it easier for individuals to communicate virtually; and form groups according to their interests. This phenomenon further increases the dependence of society and consumers on smart phones. This condition allows small entrepreneurs to conduct online marketing activities so that they can minimize advertising and promotion costs. The efforts made by small entrepreneurs of local culinary products are to form learning communities. They work together to adapt to change by improving product quality and packaging, building brands and marketing communication strategies. The empowerment model for small entrepreneurs through learning together in a community can be conducted in synergy between elements of the government, universities and the entrepreneur community. The government in this case plays a role in activating and protecting small entrepreneurs, while universities and entrepreneurial communities play a role in empowering small entrepreneurs and building their capacities.

\section{ACKNOWLEDGMENT}

We would like to extend our deepest appreciation for the Islamic Development Bank which has provided research grants to conclude this research. In addition, we owe our gratitude to Mrs. Corry, Mr. Eby, Mr. Sukarno, Mr. Ceppy, Mr. Asyrof, Mr. Agus Mulyadi, Mrs. Ratu Toety, Mrs. Ekawati, Mrs. Mulyati, for allocating time to participate in this research and sharing their experiences and knowledge. 


\section{REFERENCES}

[1] Consalvo, Mia \& Charles. 2011. The Handbook of Internet Studies. Wiley-Blackwell Publishing.

[2] Harvard Bussines School 2006. The Essentials of Corporate Communication and Marketing Communications. Boston: Harvard Business School Prss.

[3] Hatten, Timothy. S. (1997). Small Business; Entrepreneurship and Beyond. Prince Hall Inc. New Jersey.

[4] Latan, Hengky. 2013. Structural Equation Modeling. Konsep dan Aplikasi. Menggunakan Program Lisrel 8.80. Penerbit Alfabeta. Bandung.

[5] Lutterell, Regina. 2015. Social Media; How to Engage, Share, and Connect. Rowman \& Littlefield Publisher. UK.

[6] Neuman, Lawrence. W. 2011. Metode Penelitian Sosial; Pendekatan Kualitatif dan Kuantitatif. Edisi 7 Edisi bahasa Indonesia. Penerbit Indeks.

[7] Rogers, Everett. M. 1983. Diffusion of Innovations. Macmillan Publisher. New York USA.

[8] Ryan, Damian. 2009. Understanding digital marketing: marketing strategies for engaging the digital generation. Kogan Page Limited London UK, Philadelphia USA.

[9] Sciarelli, Mauro. 2017. Mediating Service Recovary Satisfaction in the Relationship between Internet Service Recovary and Customer Loyalty. International Journal of Business and Management. Vol 12. No. 10

[11] Shimp, Terence A. 2003. Promotion Management \& Marketing Communication. The Dryden Press University of South Carolina.

[12] Singhal, Arvind\& Dearing, James W. 2006. Communication of Innovations; Journey with EV Rogers. Sage Publications. New Delhi.

[13] Strauss, William. Howe, Neil. 2000. Millennials Rising: The Next Great Generation. Sage Publication. New Delhi.

[14] Thurlow, Crispin. et al. 2004. Computer-Mediated Communication; Social Interaction and The Internet. Sage Publication. California.

[15] Ivanauskas, Giedrius. 2009. The Evaluation of Social Media Effect on Marketing Communications: The UK Consumers Perspective. MA International Business and Marketing.

[16] Kearney, A.T. 2015. Economic growth in South East Asia; Economic Intelligent Unit. E-Commerce. Singapore.

\section{Journals}

[17] Austin, M. S., \& Graiko, S. 2013. Digital and Social Media in the Purchase-Decision Process: A Special Report from the Advertising Research Foundation. Journal of Advertising Research, 52(4), 479. doi: 10.2501/jar-52-4-479-489.

[18] Bruhn, Manfred all. 2012. Are social media replacing traditional media in terms of brand equity creation?
Journal of the Management Research Review. Vol. 35. No. 9.

[19] Galperin, Hernan. 2017. Why Are Half of Latin Americans Not Online? A Four-Country Study of Reasons for Internet Nonadoption. International Journal of Communication. Volume 11

[20] Hansel, Kyle \& Deis, Michele H. 2010. Using media to Increase Advertising and Improve Marketing. Journal of Entrepreneurial Executive. Volume 15

[21] Ketter, Eran \& Eli, Avraham. 2012. The Social Revolution of Place Marketing; The Growing power of Users in Social Media Campaigns. Journal of Branding and Public Diplomacy.Vol.8. 4. 285-294.

[22] Khang, Hyoungkoo. et al. 2012. Social Media Research in Advertising, Communication, Marketing, and Public Relations, 1997-2010. Journalism \& Mass Communication Quarterly.

[23] Kietzmann, J. H., Silvestre, B. S., McCarthy, I. P., \& Pitt, L. F. 2012. Unpacking the social media phenomenon: towards a research agenda. Journal of Public Affairs, 12(2), 109-119. doi: 10.1002/pa.1412 Labs| Global Pulse.

[24] Kunz, Michele B., et al. 2011. Fans, Friends, and Followers; Social Media in the Retailers' Marketing Mix. Journal of Applied Business and Economics. 12(3).

[25] Lopez, Manuela \& Sicilia, Maria. 2013. How WOM Marketing Contributes to New Product Adoption. European Journal of Marketing. Vol 47.

[26] Lorenzo-Romero, C., \& Alarcón-del -Amo, M.-d. C. 2012. Segmentation of Users of Social Networking Websites. Social Behavior and Personality: an international journal, 40(3), 401414. doi: 10.2224/sbp.2012.40.3.401.

[27] Ludwig, S., de Ruyter, K., Friedman, M., Brüggen, E. C., Wetzels, M., \&Pfann, G. 2013. More Than Words: The Influence of Affective Content and Linguistic Style Matches in Online Reviews on Conversion Rates. Journal of Marketing, 77(1), 87-103.

[28] Metha, mind \& Anand. Richa. 2012. Social Media and Micro Entrepreneurs; Lifestyle Marketing. Journal of Entrepreneurship and Management. Volume1 Issue 3 October

[29] Moghavvemi, eighth, et all. 2012. The entrepreneur's perception on information technology innovation adoption; an empirical analysis of the role of precepting events on usage behavior. Journal of Marketing Communication Research, 24(3), 9-13.

[30] Naseri, Mohammad Bakher \& Eliot, Greg. 2014. Role of demographics, social connectedness and prior internet experience in the adoption of online shopping; applications for direct marketing. Journal of Targeting Management and Analysis for Marketing. Vol. 19, 2, 6964

[31] Nekmat, E. 2012. Message Expression Effects in Online Social Communication. Journal of Broadcasting \& 
Electronic Media, 56(2), 203-224. doi: 10.1080/08838151.

[32] Rangkuti Parlaungan Adil, 2009. Jurnal Litbang Pertanian 28 (2).

[33] Romaniuk, J. 2013. Are You Ready for the Next Big Thing? New Media Is Dead! Long Live New Media! Journal of Advertising Research, 52(4), 397. doi: 10.2501/jar-52-4-397-399.

[34] Slyke, Craig Van,.Et all. 2007. Perceived mass and the adoption of a communication technology. European Journal of Information Systems. Vol. 16

[35] Stieglitz, S., \& Dang-Xuan, L. 2013. Emotions and Information Diffusion in Social Media- Sentiment of Microblogs and Sharing Behavior. Journal of Management Information Systems, 29(4), 217-248. doi: 10.2753/mis0742-1222290408.

[36] Tariq, Mohammad \& Wahid, Fazal. 2011. Assessing Effectiveness of Social Media and Traditional Marketing Approaches in Terms of Cost and Target Segment Coverage. Journal of Institute of Interdisciplinary Business Research. 